\title{
Hybrid or reverse hybrid for total hip arthroplasty?
}

\author{
Total kalça artroplastisinde hibrid mi, ters hibrid mi?
}

\author{
O. Şahap Atik, M.D. \\ Department of Orthopedics and Traumatology, Medical Faculty of Gazi University, Ankara, Turkey
}

When reverse hybrid total hip arthroplasty (cemented thick all poly acetabular cup and uncemented hydroxyapatite coated femoral stem) was initiated in Turkey by this author in 1989, there was too much negative criticism. ${ }^{[1,2]}$ The reason for preferring this option was earlier personal experience and the literature data. ${ }^{[3,4]}$ Currently, to the author's knowledge, there is no other orthopedic surgeon in the country performing this technique.

Recent data now further supports the advantages of using reverse hybrid. ${ }^{[5,6]}$ At 31 years, survival with revision for a loose stem is $72.5 \%$ and for a loose acetabular component 53.7\%..$^{[5]}$ Uncemented cup components had a higher risk of cup revision due to aseptic loosening, whereas uncemented stem components had a lower risk of stem revision due to aseptic loosening when compared to cemented components in the Swedish Hip Arthroplasty Register evaluating 170,413 operations. ${ }^{[6]}$

A meta-analysis for the comparison of cemented and uncemented fixation in total hip replacement showed that cemented titanium stems and uncemented threaded cups were associated with poor survival..$^{[7]}$
The use of reversed hybrid total hip arthroplasty with an uncemented stem and a cemented cup continues to increase in Europe, particularly in Sweden, and the author's choice remains the same.

\section{REFERENCES}

1. Atik OS, Bolukbasi S, Cila E. Freeman total hip arthroplasty. Eklem Hastalik Cerrahisi 1991;3:1-3.

2. Atik OS, Sener S, Ferhat S. Reverse hybrid versus hybrid application in total hip arthroplasty. Eklem Hastalik Cerrahisi 1994;5:28-9.

3. McCoy TH, Salvati EA, Ranawat CS, Wilson PD Jr. A fifteenyear follow-up study of one hundred Charnley low-friction arthroplasties. Orthop Clin North Am 1988;19:467-76.

4. Le Tournel E. Revison of uncemented proshtesis. Proceedings of the Symposium of Revision Arthroplasty. 2-4 March, 1983, London: Franklin Scientific Publications; 1983. p. 113.

5. Wroblewski BM, Siney PD, Fleming PA. Charnley lowfriction arthroplasty: survival patterns to 38 years. J Bone Joint Surg [Br] 2007;89:1015-8.

6. Hailer NP, Garellick G, Kärrholm J. Uncemented and cemented primary total hip arthroplasty in the Swedish Hip Arthroplasty Register. Acta Orthop 2010;81:34-41. doi: 10.3109/17453671003685400.

7. Morshed S, Bozic KJ, Ries MD, Malchau H, Colford JM Jr. Comparison of cemented and uncemented fixation in total hip replacement: a meta-analysis. Acta Orthop 2007;78:315-26.

\footnotetext{
- Correspondence: O. Şahap Atik, M.D. Gazi Üniversitesi Tıp Fakültesi Ortopedi ve Travmatoloji Anabilim Dalı, 06500 Beşevler, Ankara, Turkey. Tel: +90 312 - 2025528 Fax: +90 312 - 2129008 e-mail: satikmd@gmail.com
} 